\title{
The structural effect of Methyl substitution on the binding of Polypyridyl Ru-dppz Complexes to DNA
}

Article

Accepted Version

Hall, J. P., Beer, H., Buchner, K., Cardin, D. J. and Cardin, C. J. (2015) The structural effect of Methyl substitution on the binding of Polypyridyl Ru-dppz Complexes to DNA.

Organometallics, 34 (11). pp. 2481-2486. ISSN 1520-6041 doi: https://doi.org/10.1021/om501208x Available at https://centaur.reading.ac.uk/40116/

It is advisable to refer to the publisher's version if you intend to cite from the work. See Guidance on citing.

To link to this article DOI: http://dx.doi.org/10.1021/om501208x

Publisher: American Chemical Society

All outputs in CentAUR are protected by Intellectual Property Rights law, including copyright law. Copyright and IPR is retained by the creators or other copyright holders. Terms and conditions for use of this material are defined in the End User Agreement.

www.reading.ac.uk/centaur 
Central Archive at the University of Reading

Reading's research outputs online 


\title{
The Structural Effect of Methyl Substitution on the Binding of $\left[R u(T A P)_{2}(d p p z)\right]^{2+}$ to DNA
}

\author{
James P. Hall ${ }^{\dagger \dagger}$, Hanna Beer ${ }^{\dagger}$, Katrin Buchner ${ }^{\dagger}$, David J. Cardin ${ }^{\dagger}$ and Christine J. Cardin ${ }^{\dagger *}$ \\ $\dagger$ Department of Chemistry, University of Reading, Whiteknights, Reading, Berkshire, RG6 6AD, UK \\ †Diamond Light Source, Harwell Science and Innovation Campus, Fermi Avenue, Didcot, Oxfordshire, OX11 0QX, UK \\ Supporting Information Placeholder
}

\begin{abstract}
Polypyridyl ruthenium complexes have been intensively studied and possess photophysical properties which are both interesting and useful. They can act as probes for DNA, with a substantial enhancement in emission when bound, and can induce DNA damage upon photoirradiation. Therefore the synthesis and characterization of DNA binding of new complexes is an area of intense research activity. While the knowledge of how the binding of derivatives compares to the parent compound is highly desirable, this information can be difficult to obtain. Here we report the synthesis of three new methylated complexes, $\left[\mathrm{Ru}(\mathrm{TAP})_{2}(\mathrm{dppz}-10-\mathrm{Me}) .2 \mathrm{Cl},\left[\mathrm{Ru}(\mathrm{TAP})_{2}\left(\mathrm{dppz}-10,12-\mathrm{Me}_{2}\right)\right] .2 \mathrm{Cl}\right.$ and $\left[\mathrm{Ru}(\mathrm{TAP})_{2}(\mathrm{dppz}-11-\mathrm{Me})\right] .2 \mathrm{Cl}$, and examine the consequences for DNA binding through atomic resolution X-ray crystallography. We find that the methyl groups are located in discrete positions with a complete directional preference which may help to explain the quenching behavior which is found in solution.
\end{abstract}

\section{INTRODUCTION}

Ruthenium polypyridyl complexes have been intensively studied since the mid-1980s ${ }^{1,2}$ due to the interesting, and useful, photophysical properties which they possess. Their interactions with DNA have been extensively studied as the compounds are able to act as DNA probes ${ }^{3}$, can induce DNA dam$\mathrm{age}^{4}$ and, when they possess a dipyrido[3,2-a:2', $3^{\prime}$-c]phenazine (dppz) group, are able to intercalate between DNA base pairs. A large number of complexes have been reported, as the photophysical properties of the compounds can be tuned by introducing seemingly small changes into the ancillary ligands 5 .

An example of this sensitivity is the changing of the ancillary ligands from 1,10-phenanthroline (phen) to 1,4,5,8tetraazaphenanthrene (TAP), which alters the luminescence behaviour of the compound. $\left[\mathrm{Ru}(\mathrm{phen})_{2}(\mathrm{dppz})\right]^{2+}$ luminesces when bound to DNA but does not in an aqueous environment, due to quenching by water $^{6-8}$. However, $\left[\mathrm{Ru}(\mathrm{TAP})_{2}(\mathrm{dppz})\right]^{2+}$ luminesces in aqueous solution but has its emission quenched by electron transfer from guanine when bound to DNA ${ }^{9-11}$.

Changes to the dppz group have also been investigated, with $\left[\mathrm{Ru}(\text { phen })_{2}(1,10\right.$-phenanthrolino[5,6- $b] 1,4,5,8,9,12$ -

hexaazatriphenylene) $]^{2+}$ being found to emit less than the parent $\left[\mathrm{Ru}(\mathrm{phen})_{2}(\mathrm{dppz})\right]^{2+}$, but bind with the same strength ${ }^{12}$. In addition to this the complexes $\left[\mathrm{Ru}(\mathrm{phen})_{2}(\mathrm{dppz}-10-\mathrm{X})\right]^{2+}$, where $\mathrm{X}=\mathrm{OH}$ or $\mathrm{NO}_{2}$, have been reported, and it was found that, while both could bind to DNA via intercalation, the introduction of an electron-withdrawing substituent results in a greater binding affinity ${ }^{13}$ due to electronic effects. It has also been reported that the placing of methyl substituents onto the dppz group of $\left[\mathrm{Cr}(\text { phen })_{2}(\mathrm{dppz})\right]^{3+}$, to give $\left[\mathrm{Cr}(\mathrm{phen})_{2}(\mathrm{dppz}-\right.$ $\left.\left.11,12-\mathrm{Me}_{2}\right)\right]^{3+}$, increases the binding strength of the compound $^{14}$ due to the hydrophobic effect of the alkyl group in the DNA groove. Similar effects have been found for dipyridoquinoxaline complexes ${ }^{15}$. Electronic differences could account for some binding preferences but it is also possible that introducing substitutions into the dppz group could have steric consequences, and therefore promote different binding motifs.

Whilst the binding of Ru-dppz compounds to DNA is an area of intense study, it was not until recently ${ }^{16}$ that the first crystal structure was reported. This structure showed how $\Lambda$ $\left[\mathrm{Ru}(\mathrm{TAP})_{2}(\mathrm{dppz})\right]^{2+}$ binds to DNA of sequence d(TCGGCGCCGA). We subsequently reported the structure of this DNA duplex bound to a ruthenium complex possessing an asymmetrically substituted dppz group, [Ru(TAP) $)_{2}(\mathrm{dppz}-$ $11-\mathrm{Cl})]^{2+}$, and found that the chlorine was directed preferentially away from the major groove of the DNA $^{17}$. Here we report the synthesis of three methylated ruthenium complexes and explore how these, along with an additional derivative (Figure 1) bind to DNA as shown by atomic resolution X-ray crystal structures.

\section{RESULTS}

\section{X-RAY CRYSTAL STRUCTURES}

Four X-ray crystal structures were obtained, containing DNA of sequence d(TCGGCGCCGA) bound to each of the complexes displayed in Figure 1b-e. The overall structure is illustrated in Figure 2a. The structures, numbered 1-4 as displayed in Table 1, show how placing a methyl substituent in different positions on the dppz group can affect the direction in which the Me is directed. Apart from the directionality of the methyl group(s), all four structures are isostructural with our previously reported work for the dppz complex and therefore the general features are present throughout the set presented here. Despite the crystallization solution containing the racemic compound only the $\Lambda$ enantiomer is in the structure. 
a

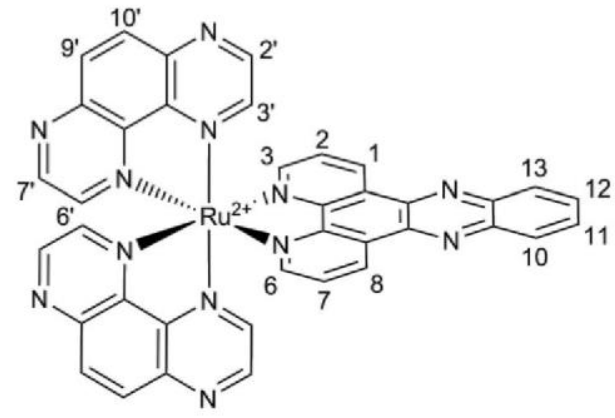

b<smiles>CN=C1C=CC=C(C)C1=NC</smiles>

C<smiles>Cc1ccc2c(n1)=NCCN=2</smiles>
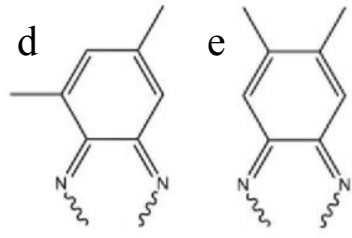

Figure 1. (a) Chemical diagram of $\Lambda$-[Ru(TAP $)_{2}(\mathrm{dpp} z]^{2+}$ illustrating the TAP and dppz numbering scheme. The positions of methyl substitution on the dppz group for the complexes reported here are also illustrated in (b) dppz-10-Me, (c) dppz-11-Me, (d) dppz-10,12- $\mathrm{Me}_{2}$ and (e) dppz-11,12- $\mathrm{Me}_{2}$.

\section{INTERCALATION SITE}

The complex is intercalated into the minor groove, through the substituted-dppz group, into the $\mathrm{T}_{1} \mathrm{C}_{2}$ step in the DNA duplex. The end of the dppz group sits in the major groove of the DNA. Due to the two-fold crystallographic axis which runs through the center of the duplex, perpendicular to the helical axis, the complex is also intercalated into the symmetry equivalent $\mathrm{G}_{9} \mathrm{~A}_{10}$ step at the opposite end of the DNA. The long axis of the dppz group is offset from the $\mathrm{C}_{2}-\mathrm{G}_{9}$ hydrogen bonds by approximately $51^{\circ}$ and therefore intercalation into this site occurs with a canted geometry. Intercalation into this step also causes $A_{10}$ to flip out of the duplex and form a reverse Watson-Crick base pair with $\mathrm{T}_{1}$ from a neighbouring duplex. The ordered water structure in all four structures is remarkably similar around the intercalation site. Three additional water molecules are present at the end of the dppz group in structure 1 suggesting that when the complex only a 10 -Me substituent fewer water molecules are displaced.

\section{SEMI-INTERCALATION SITE}

A TAP group (TAP 1), from the ruthenium complex, is semi-intercalated into the duplex at the symmetry equivalent $\mathrm{G}_{3} \mathrm{G}_{4}$ and $\mathrm{C}_{7} \mathrm{C}_{8}$ steps. This induces a $51^{\circ}$ kink into the helix at each site. This mode of interaction is stabilized by the presence of a $\mathrm{Ba}^{2+}$ cation which is bound to $\mathrm{G}_{3}(\mathrm{~N} 7)$ and is bifurcated to $\mathrm{G}_{4}$ (Figure 2b). a

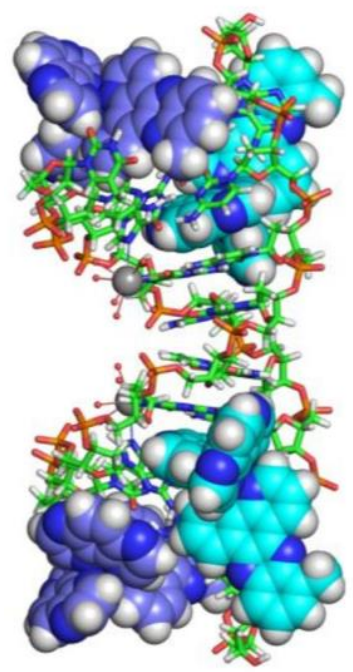

b

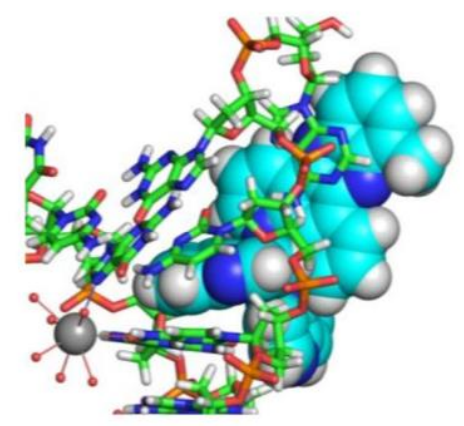

Figure 2. (a) An overall view of the DNA duplex, with all four interacting complexes, in structure 1. (b) A close up of the semiintercalation site, with coordinated $\mathrm{Ba}^{2+}$ cation. Carbon atoms in the intercalating complexes are coloured purple and carbon atoms from semi-intercalating complexes are cyan. Other atoms are coloured according to type with phosphorus in orange, oxygen in red, nitrogen in blue, barium in silver, carbon in green and hydrogen in white.

\section{DIRECTIONAL PREFERENCE}

When substitutions are introduced into the dppz group, they can be placed to either fit with, or to remove, the $\mathrm{C}_{2}$ rotation axis which runs down the long axis of the group. If placed asymmetrically, the complex loses its 2-fold rotational symmetry axis and as such can bind with the groups pointed in one of two directions. X-ray crystallography allows us to quantify this binding preference as, with high resolution data, sites with a fractional occupancy in the crystal can be observed.

Here, three complexes are used which possess asymmetric substitutions. Structure 1 shows the consequences of placing a methyl group in the 10- position on the dppz, removing the twofold rotational symmetry of the metal complex. While it could be expected that the methyl presents in two positions, each with a $50 \%$ occupancy, the group is actually exclusively directed into the major groove and directed towards the pyrimidine side of the intercalated step (Figure 3a). The opposite is true for structure 2, which shows that when a methyl group is placed in the 11- position it is directed toward the purine side of the DNA and away from the major groove (Figure 3b). Structure 3 shows the effect of introducing two methyl substitutions in an asymmetric manner, at the 10- and 12- positions on the dppz group (Figure 3c). Again, the methyl groups are found only in one location, with the 10-Me directed into the major groove on the pyrimidine side of the duplex and the 12Me away from the groove on the purine side.

In structures 1-3, no methyl group was observed protruding into the major groove on the pyrimidine side of the duplex. However in structure four, which contains [Ru(TAP) $)_{2}(\mathrm{dppz}-$ $\left.\left.11,12-\mathrm{Me}_{2}\right)\right]^{2+}$, one methyl is located on the pyrimidine side of the duplex with the remaining substituent located directed toward the purine bases (Figure 3d). The position of the methyl group was assigned on the basis of a $6 \sigma$ peak in the $F_{o}-F_{c}$ difference map, which is illustrated in Figure S1 in the supplementary information 

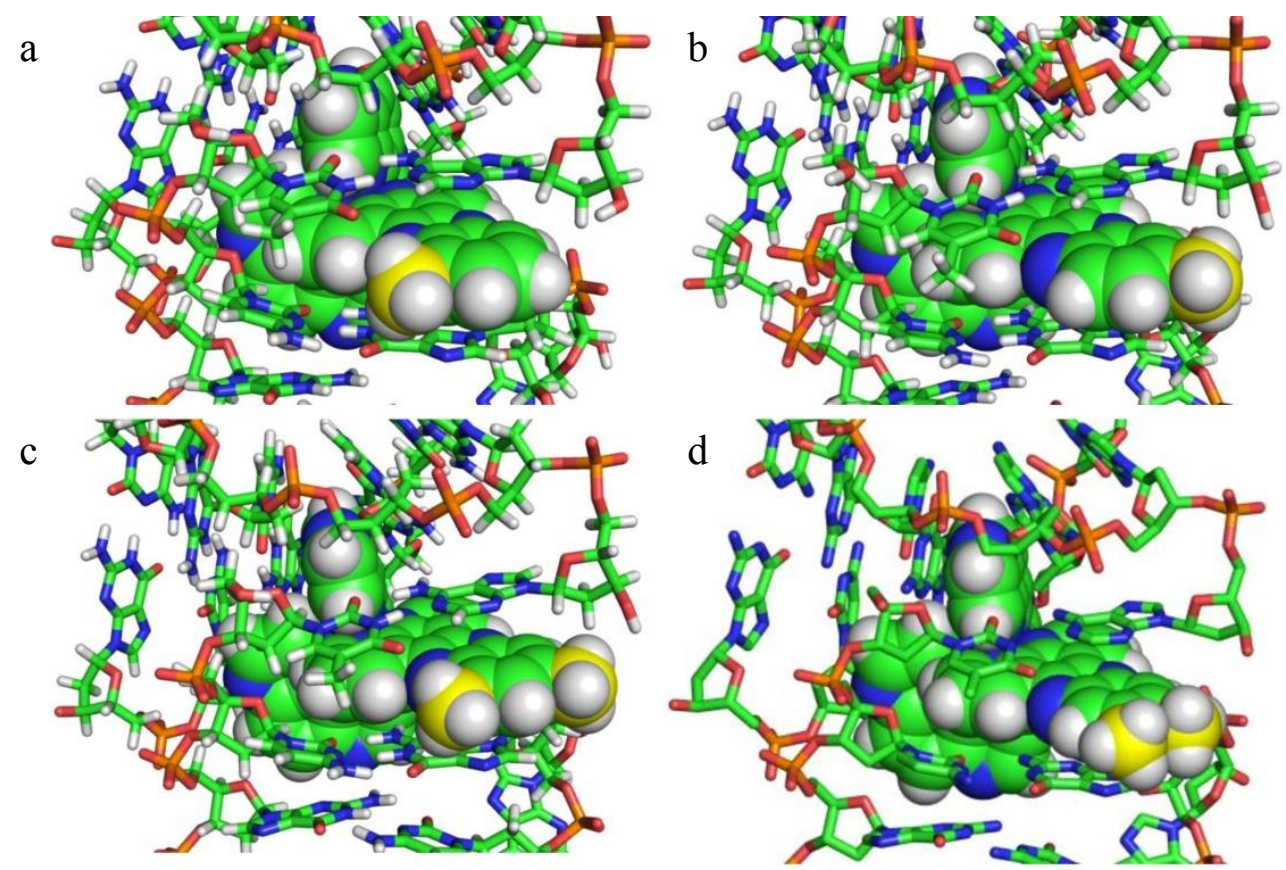

Figure 3. The intercalation site is shown for each structure. (a) $\left[\mathrm{Ru}(\mathrm{TAP})_{2}(\mathrm{dppz}-10-\mathrm{Me})\right]^{2+}$, (b) $\left[\mathrm{Ru}(\mathrm{TAP})_{2}(\mathrm{dppz}-11-\mathrm{Me})\right]^{2+}$, (c) $\left.\mathrm{Ru}(\mathrm{TAP})_{2}\left(\mathrm{dppz}-10,12-\mathrm{Me}_{2}\right)\right]^{2+}$ and (d) $\left[\mathrm{Ru}(\mathrm{TAP})_{2}\left(\mathrm{dppz}-11,12-\mathrm{Me}_{2}\right)\right]^{2+}$. The purine side of the duplex is to the right of each diagram with the pyrimidine side on the left. The methyl groups are shown in yellow with other atoms coloured according to type with phosphorus in orange, oxygen in red, nitrogen in blue, carbon in green and hydrogen in white. Hydrogen atoms have not been added to the final model of structure 4 but are shown, at calculated positions, on the Ru complex.

Table 1. Selected crystallographic data processing and refinement statistics.

\begin{tabular}{|c|c|c|c|c|}
\hline Structure Number & 1 & 2 & 3 & 4 \\
\hline Complex & $\begin{array}{l}{\left[\mathrm{Ru}(\mathrm{TAP})_{2}(\mathrm{dppz}-10-\right.} \\
\mathrm{Me})]^{2+}\end{array}$ & $\begin{array}{l}{\left[\mathrm{Ru}(\mathrm{TAP})_{2}(\mathrm{dppz}-11-\right.} \\
\mathrm{Me})]^{2+}\end{array}$ & $\begin{array}{l}{\left[\mathrm{Ru}(\mathrm{TAP})_{2}(\mathrm{dppz}-10,12-\right.} \\
\left.\left.\mathrm{Me}_{2}\right)\right]^{2+}\end{array}$ & $\begin{array}{l}\Lambda- \\
{\left[\mathrm{Ru}(\mathrm{TAP})_{2}(\mathrm{dppz}-\right.} \\
\left.\left.11,12-\mathrm{Me}_{2}\right)\right]^{2+}\end{array}$ \\
\hline \multicolumn{5}{|l|}{ Data Processing } \\
\hline Space group & $P 4_{3} 2_{1} 2$ & $P 4_{3} 2_{1} 2$ & $P 4_{3} 2_{1} 2$ & $P 4_{3} 2_{1} 2$ \\
\hline Cell Dimensions, $\AA$ & $42.2,42.2,39.6$ & $42.1,42.1,39.2$ & $42.2,42.2,39.6$ & $42.4,42.4,39.6$ \\
\hline Resolution, A & $21.14-0.97(1.00-0.97)^{*}$ & $28.70-1.05(1.08-1.05)$ & $17.05-0.89(0.91-0.89)$ & $\begin{array}{l}42.4-1.24 \\
1.24)\end{array}$ \\
\hline $\mathrm{R}_{\mathrm{pim}}$ & $0.018(0.273)$ & $0.020(0.504)$ & $0.018(0.344)$ & $0.026(0.217)$ \\
\hline $\mathrm{I} / \sigma \mathrm{I}$ & $24.2(2.6)$ & $21.8(2.1)$ & $23.5(2.2)$ & $20.2(3.5)$ \\
\hline Completeness, $\%$ & $95.9(98.7)$ & $99.1(97.7)$ & $98.5(95.9)$ & $99.9(100)$ \\
\hline Multiplicity & $6.3(4.8)$ & $6.2(6.3)$ & $6.2(6.1)$ & $10(10.2)$ \\
\hline \multicolumn{5}{|c|}{ *Outer shell statistics in parentheses } \\
\hline \multicolumn{5}{|l|}{ Refinement } \\
\hline No. Reflections & 19713 & 15996 & 26155 & 10212 \\
\hline $\mathrm{R}_{\mathrm{work}} / \mathrm{R}_{\text {free }}$ & $0.08 / 0.09$ & $0.09 / 0.10$ & $0.09 / 0.10$ & $0.10 / 0.12$ \\
\hline \multicolumn{5}{|l|}{ No. Atoms } \\
\hline DNA & 315 & 315 & 315 & 202 \\
\hline Ligands & 78 & 78 & 80 & 55 \\
\hline Water & 115 & 77 & 92 & 101 \\
\hline PDB ID & 4MJ9 & $4 \times 18$ & $4 X 1 A$ & 4E8S \\
\hline
\end{tabular}



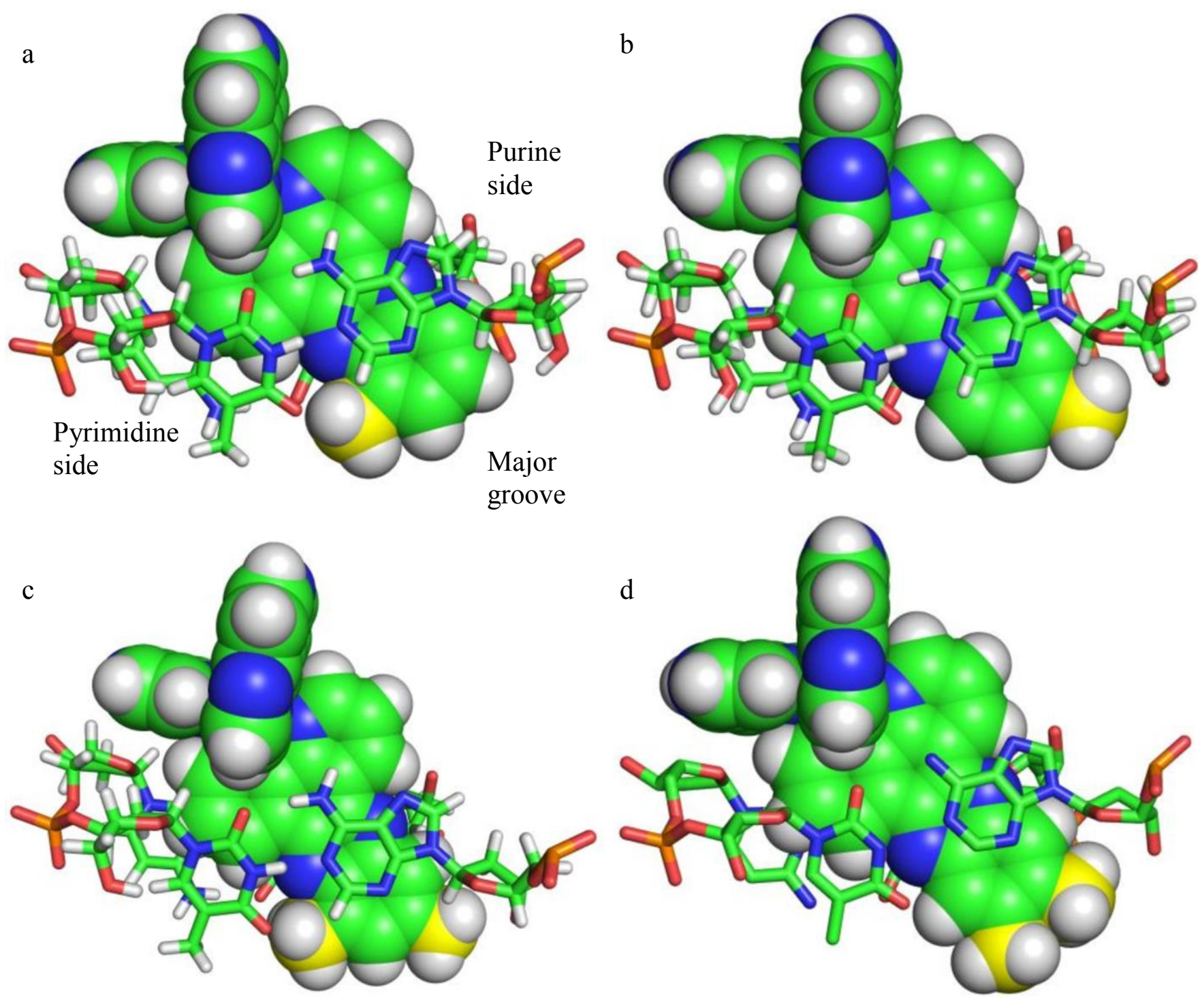

Figure 4. A view of the intercalation site in structures 1-4. (a) In structure 1 the 10-Me group is directed into the major groove away from the potential clash with the $\mathrm{A}_{10}$ sugar on the purine side of the intercalation site. (b) The 11-Me group is directed away from the major groove, toward the purine side of the intercalation site. (c) The positions of the 10 and 12-Me groups are the perfect superposition of the 10-Me in structure 1 and 11-Me in structure 2. (d) The 11,12-Me groups are located in the major groove. The methyl carbons are coloured yellow with all other atoms coloured according to element with nitrogen in blue, hydrogen in white, carbon in green, oxygen in red and phosphorus in orange. In (d) the DNA hydrogen atoms are not present in the crystal structure and are therefore omitted in the Figure. They have been added, at calculated positions, for the complex.

\section{DISCUSSION}

We have been able to synthesise three novel methylated derivatives of $\left[\mathrm{Ru}(\mathrm{TAP})_{2}(\mathrm{dppz})\right] \cdot \mathrm{Cl}_{2}$. The X-ray structures presented here clearly demonstrate that all four derivatives are able to bind with the same orientation and intercalation depth as the non-methylated parent complex and therefore the only differences between the structures are in the position of the methyl groups. However, it is the position of these groups which are of interest as they can have a profound effect on the observed photophysics of similar complexes.

In structure 1 , the binding of $\left[\mathrm{Ru}(\mathrm{TAP})_{2}(\mathrm{dppz}-10-\mathrm{Me})\right]^{2+}$ occurs with an angled geometry and with the methyl substituent directed exclusively into the major groove. It has previously been reported that the quenching of the emission of $\left[\mathrm{Ru}(\mathrm{phen})_{2}(\mathrm{dppz})\right]^{2+}$ by water ${ }^{7}$ is dependent on the number of hydrogen bonds between the dppz nitrogen atoms and water.
Quenching of the emission of the complex can be reduced by the addition of a methyl group at the 10 position on the dppz as this disrupts the hydration cage around the complex ${ }^{18}$. Structure 1 demonstrates that the nitrogen on the nonmethylated side of the DNA is completely water inaccessible when it is intercalated into DNA with an angled geometry. The combined effect of the methyl group and the DNA bases partially occlude the dppz nitrogen on the methylated side of the dppz and would therefore reduce its propensity for forming H-bonds with solvent molecules. Additionally, if the complex were rotated by $180^{\circ}$, down the long axis of the dppz group, placing the methyl group on the opposite side the substituent may clash with the $\mathrm{A}_{10}$ sugar. It is therefore interesting to consider whether angled intercalation could occur if a methyl group were added to both the 10 and 13 position, to give $\left[\mathrm{Ru}(\mathrm{TAP})_{2}\left(\mathrm{dppz}-10,13-\mathrm{Me}_{2}\right]^{2+}\right.$, or whether binding could only 
occur with a perpendicular geometry, which we have previously reported at TA steps ${ }^{19}$.

Structure 2, $\quad\left[\mathrm{Ru}(\mathrm{TAP})_{2}(\mathrm{dppz}-11-\mathrm{Me})\right]^{2+} \quad$ with $\mathrm{d}$ (TCGGCGCCGA), is of particular interest. The 11-Me substituent would not clash with the DNA if the complex were rotated $180^{\circ}$ down the long axis of the dppz group, to place the group it in its alternative position. Additionally, if the methyl group were directed into the major groove it seems likely that it would displace more water molecules than directed away, where one side of the group is close to the $A_{10}$ sugar and is therefore shielded from the solvent. It could be possible that binding with the 11-Me group on the purine side of the step is therefore more favourable because the methyl group helps the compound to stay intercalated into the DNA and act as a molecular "hook", reducing the ability of the complex to rotate in the intercalation cavity and therefore forming a more stable interaction. The position of the 11-Me group is mirrored in structure 3 , containing $\left[\mathrm{Ru}(\mathrm{TAP})_{2}\left(\mathrm{dppz}-10,12-\mathrm{Me}_{2}\right)\right]^{2+}$, and complemented by the 10-methyl group also in the same position as structure 1 . This highlights that binding with an angled orientation, and with a methyl group in what would be the 13 position, is highly disfavoured.

$\left[\mathrm{Ru}(\mathrm{TAP})_{2}\left(\mathrm{dppz}-11,12-\mathrm{Me}_{2}\right)\right]^{2+}$ has been shown to bind more strongly than the parent compound, $\left[\mathrm{Ru}(\mathrm{TAP})_{2}(\mathrm{dppz})\right]^{2+}$, in solution ${ }^{20}$ and this has been attributed to the increased displacement of water making binding entropically favourable. Structure 4 shows that the intercalation depth and binding geometry of $\left[\mathrm{Ru}(\mathrm{TAP})_{2}\left(\mathrm{dppz}-11,12-\mathrm{Me}_{2}\right)\right]^{2+}$ are consistent with its parent compound and therefore it seems likely that the increase in binding constant is not a steric consequence of methylating the complex. It has also been found that methyl groups in the 11 and 12 position can disrupt the water cage around the complex and reduce emission quenching, albeit to a lesser extent than with $\left[\mathrm{Ru}(\mathrm{phen})_{2}(\mathrm{dppz}-10-\mathrm{Me})\right]^{2+}$ presumably because the groups do not directly shield the dppz pyrazine $\mathrm{N}$ atoms. Our structure shows that the accessibility of these dppz-N atoms is not affected by the introduction of methyl groups at the 11 and 12 positions, confirming that the difference in emission behaviour must be due to non-steric effects.

The binding preferences observed here are very different to those observed for $\left[\mathrm{Ru}(\mathrm{TAP})_{2}(\mathrm{dppz}-11-\mathrm{Cl}]^{2+}\right.$ where the chlorine substituent is disordered over two sites with a partial directional preference. The effect of methylation can clearly affect the binding of the complex and can promote a single, unambiguous binding motif. This result may prove useful in the future design of complexes designed to exploit groups close to a particular binding site and could assist with the production of complexes which are able to bind with a high level of specificity to a specific target.

\section{CONCLUSION}

We have reported the synthesis of three novel methylated polypyridyl ruthenium complexes and explored the consequences to binding by X-ray crystallography. The X-ray crystal structures show that the addition of a methyl group to the end of the dppz moiety promotes a single binding mode despite the potential for binding with a disordered motif. The structures also show that, when binding with an angled geometry, the dppz nitrogens can be partially or completely shielded from solvent. These results will assist with the interpretation of solution data based in the knowledge of new binding modes and could prove useful in the design and synthesis of polypyridyl ruthenium complexes

\section{EXPERIMENTAL SECTION}

\section{PREPARATION OF THE RUTHENIUM COMPLEXES}

The complexes $\left[\mathrm{Ru}(\mathrm{TAP})_{2}\left(\mathrm{dppz}^{\prime}\right)\right] \mathrm{X}_{2} \quad(\mathrm{TAP}=1,4,6,9-$ tetraazaphenanthrene; dppz $=$ a substituted dipyrido[3,2-a:2',3'c]phenazine) were prepared from $\left[\mathrm{Ru}(\mathrm{TAP})_{2} \mathrm{pd}\right] \mathrm{Cl}_{2}$, $(\mathrm{pd}=$ phenanthroline-5,6-dione), and purified as previously reported ${ }^{17}$. Data for the new complexes are as follows.

$\left[\mathrm{Ru}(\mathrm{TAP})_{2}(10-\mathrm{Medppz})\right]\left(\mathrm{PF}_{6}\right)_{2}{ }^{-}{ }^{1} \mathrm{H}$ NMR $(400 \mathrm{MHz}$, acetone $) \delta$ $9.78,1 \mathrm{H}$, dd $(\mathrm{J}=6.04, \mathrm{~J}=1.72 \mathrm{~Hz}) ; 8.87,2 \mathrm{H}, \mathrm{dd}(\mathrm{J}=6.44, \mathrm{~J}=1.64$ $\mathrm{Hz}) ; 8.64,1 \mathrm{H}, \mathrm{d}(\mathrm{J}=8.28 \mathrm{~Hz}) ; 8.55,1 \mathrm{H} \mathrm{m} ; 8.48,2 \mathrm{H}, \mathrm{m} ; 8.12,2 \mathrm{H} \mathrm{m}$; $7.85,2 \mathrm{H}, \quad \mathrm{m} ; 3.04, \quad 3 \mathrm{H}, \quad$ s. Mass spectrum: (FTMS, ESI) $\left[\mathrm{Ru}(\mathrm{TAP})_{2}(\mathrm{dppz})\right]^{2+}$ Obs: 381.0644 ; calc for $\left[\mathrm{C}_{39} \mathrm{H}_{24} \mathrm{~N}_{12}\right]^{2+} 381.0640$ (err. $1.10 \mathrm{ppm})$.

$\left[\mathrm{Ru}(\mathrm{TAP})_{2}(11-\mathrm{Medppz})\right]\left(\mathrm{PF}_{6}\right)_{2^{-}}{ }^{1} \mathrm{H}$ NMR $(400 \mathrm{MHz}$, acetone) $\delta$ 9.82, $1 \mathrm{H}, \mathrm{d}(\mathrm{J}=8.12 \mathrm{~Hz}) ; 9.14,1 \mathrm{H}, \mathrm{d}(\mathrm{J}=2.76 \mathrm{~Hz}) ; 9.09,1 \mathrm{H}, \mathrm{d}(\mathrm{J}=$ $2.72 \mathrm{~Hz}) ; 8.85,2 \mathrm{H}, \mathrm{m}$; ca. $8.71,1 \mathrm{H}, \mathrm{m} ; 8.43,1 \mathrm{H}, \mathrm{d}(\mathrm{J}=8.68 \mathrm{~Hz})$; $8.31,1 \mathrm{H}, \mathrm{m} ; 8.10,1 \mathrm{H}, \mathrm{dd}(\mathrm{J}=8.8,1.64 \mathrm{~Hz}) ;$ ca $8.03,2 \mathrm{H} \mathrm{m} ; 2.79,3 \mathrm{H}$ s.

$\left[\operatorname{Ru}(\mathrm{TAP})_{2}\left(11,12-\mathrm{Me}_{2} \mathrm{dppz}\right)\right] \mathrm{Cl}_{2^{-}}{ }^{1} \mathrm{H}$ NMR $\left(400 \mathrm{MHz}, \mathrm{CD}_{3} \mathrm{CN}\right) \delta$ $9.73,1 \mathrm{H}, \mathrm{dd}(\mathrm{J}=8.0, \mathrm{~J}=1,2 \mathrm{~Hz}) ; 9.00,2 \mathrm{H}, \mathrm{dd}(\mathrm{J}=8.0, \mathrm{~J}=2.8 \mathrm{~Hz})$; $8.66,2 \mathrm{H}, \mathrm{m} ; 8.33,1 \mathrm{H}, \mathrm{d},(\mathrm{J}=2.6 \mathrm{~Hz})$; ca. $8.26,2 \mathrm{H}, \mathrm{dd}(\mathrm{J}=8.8 \mathrm{~Hz}$, smaller coupling not fully resolved); $8.19,1 \mathrm{H}, \mathrm{dd}(\mathrm{J}=5.2, \mathrm{~J}=1,2$ $\mathrm{Hz}) ; 7.85,1 \mathrm{H}, \mathrm{M} ; 2.70,6 \mathrm{H}, \mathrm{s}$.

\section{CRYSTALLIZATION}

The oligonucleotide d(TCGGCGCCGA) was purchased from ADTBio (Southampton) as a HPLC purified solid. The crystallization solution contained $1 \mu \mathrm{L} 2 \mathrm{mM}$ oligonucleotide, $1 \mu \mathrm{L} 4 \mathrm{mM}$ racruthenium complex and $6 \mu \mathrm{L}$ of a solution containing $20 \mathrm{mM} \mathrm{BaCl}_{2}$, $80 \mathrm{mM} \mathrm{KCl}, 40 \mathrm{mM}$ Na-cacodylate $\mathrm{pH} 7,12 \mathrm{mM}$ spermine-tetra $\mathrm{HCl}$ and $10 \%(\mathrm{v} / \mathrm{v})$ 2-methyl-2,4-pentanediol. This was equilibrated against $1 \mathrm{ml} \mathrm{35 \% (v/v)} \mathrm{2-methyl-2,4-pentanediol.} \mathrm{Crystals} \mathrm{grew} \mathrm{in}$ approximately 1-3 weeks.

\section{DATA COLLECTION, STRUCTURE SOLUTION AND REFINEMENT}

Data for all four structures were collected on beam line I02 at Diamond Light Source. Data were processed using xia2 ${ }^{21}$, with $\mathrm{XDS}^{22}$ and Scala $^{23}$. Structures 1 and 4 were solved using molecular replacement with Phaser $^{24}$ and structure 3QRN from the Protein Data Bank ${ }^{25}$. Structures 2 and 3 were solved using the anomalous diffraction of barium with SHELXC/D/E $\mathrm{E}^{26}$. In all cases the models were built using $\mathrm{Coot}^{27}$ and refined with Refmac ${ }^{28}$. The models were then deposited in the Protein Data Bank. The $\mathrm{CCP} 4{ }^{29}$ suite was used throughout. Selected data collection and refinement statistics are in Table 1 with full experimental details in the supplementary information (Table S1).

\section{ASSOCIATED CONTENT}

\section{Supporting Information}

A Table, giving full crystallographic data collection, processing and refinement statistics along with a Figure showing how the methyl position was assigned in structure 4 is available in the supplementary information. This information is available free of charge via the internet at http://pubs.acs.org.

\section{AUTHOR INFORMATION}

\section{Corresponding Author}

* Email for C.J.C.: c.j.cardin@ reading.ac.uk 


\section{Notes}

The authors declare no competing financial interest.

\section{ACKNOWLEDGMENT}

We would like to thank Dr K. O'Sullivan and Professor J. Kelly (Trinity College Dublin) for the gift of the $\Lambda$ $\left[\mathrm{Ru}(\mathrm{TAP})_{2}(\mathrm{dppz}-11,12-\mathrm{Me})\right] \cdot \mathrm{Cl}_{2}$ which was used in this study, the synthesis of which will be shortly reported. We would also like to thank Fergus Poynton for useful discussions. We would like to thank Dr G. Winter and Professor T. Sorensen (Diamond Light Source) for useful discussions. This work was funded by BBSRC grant BB/K019279/1.

\section{REFERENCES}

(1) Barton, J. K.; Danishefsky, A.; Goldberg, J. J. Am. Chem. Soc. 1984, 106, 2172-2176.

(2) Kelly, J. M.; Tossi, A. B.; McConnell, D. J.; OhUigin, C. Nucleic Acids Res. 1985, 13, 6017-6034.

Hartshorn, R. M.; Barton, J. K. J. Am. Chem. Soc. 1992, 114, $5919-5925$.

(4) Kelly, J. M.; McConnell, D. J.; OhUigin, C.; Tossi, A. B.; Mesmaeker, A. K.-D.; Masschelein, A.; Nasielski, J. J. Chem. Soc. Chem. Comm. 1987, 24, 1821-1824.

Sentagne, C.; Chambron, J.-C.; Sauvage, J.-P.; Paillous, N. J. Photochem. Photobiol. B Biol. 1994, 26, 165-174.

Coates, C. G.; Jacquet, L.; McGarvey, J. J.; Bell, S. E. J.; AlObaidi, A. H. R.; Kelly, J. M. J. Am. Chem. Soc. 1997, 119, 7130-7136.

(7) Olofsson, J.; Önfelt, B.; Lincoln, P. J. Phys. Chem. A. 2004, 108, 4391-4398.

McKinley, A. W.; Lincoln, P.; Tuite, E. M. Dalton. T. 2013, 42, 4081-4090.

Ortmans, I.; Elias, B.; Kelly, J. M.; Moucheron, C.; KirschDeMesmaeker, A. Dalt. Trans. 2004, 668-676.

(10) Elias, B.; Kirsch-De Mesmaeker, A. Coord. Chem. Rev. 2006, $250,1627-1641$.

(11) Elias, B.; Creely, C.; Doorley, G. W.; Feeney, M. M.; Moucheron, C.; Kirsch-DeMesmaeker, A.; Dyer, J.; Grills, D. C.; George, M. W.; Matousek, P.; Parker, A. W.; Towrie, M.; Kelly, J. M. Chem. A Eur. J. 2008, 14, 369-375.

(12) Moucheron, C.; Kirsch-De Mesmaeker, A. J. Phys. Org. Chem. 1998, 11, 577-583.
Yu, H.-J.; Huang, S.-M.; Li, L.-Y.; Jia, H.-N.; Chao, H.; Mao, Z.-W.; Liu, J.-Z.; Ji, L.-N. J. Inorg. Biochem. 2009, 103, 881890.

Vasudevan, S.; Smith, J. A.; Wojdyla, M.; DiTrapani, A.; Kruger, P. E.; McCabe, T.; Fletcher, N. C.; Quinn, S. J.; Kelly, J. M. Dalt. Trans. 2010, 39, 3990-3998.

O’Donoghue, K.; Penedo, J. C.; Kelly, J. M.; Kruger, P. E. Dalt. Trans. 2005, 1123-1128.

Hall, J. P.; O’Sullivan, K.; Naseer, A.; Smith, J. A.; Kelly, J. M.; Cardin, C. J. Proc. Natl. Acad. Sci. USA. 2011, 108, 1761017614.

Hall, J. P.; Beer, H.; Buchner, K.; Cardin, D. J.; Cardin, C. J. Philos. T. R. Soc. A. 2013, 371, 20120525.

Olofsson, J.; Wilhelmsson, L. M.; Lincoln, P. J. Am. Chem. Soc. 2004, 126, 15458-15465.

Niyazi, H.; Hall, J. P.; O’Sullivan, K.; Winter, G.; Sorensen, T.; Kelly, J. M.; Cardin, C. J. Nat. Chem. 2012, 4, 621-628.

O'Sullivan, K. A Synthetic and Photophysical Study of Ruthenium Polypyridyl Enantiomers Binding to DNA, Trinity College Dublin, 2011.

Winter, G.; Lobley, C. M. C.; Prince, S. M. Acta Crystallogr. 2013, D69, 1260-1273.

Kabsch, W. Acta Crystallogr. 2010, D66, 125-132.

Evans, P. Acta Crystallogr. 2006, D62, 72-82.

McCoy, A. J.; Grosse-Kunstleve, R. W.; Adams, P. D.; Winn, M. D.; Storoni, L. C.; Read, R. J. J. Appl. Cryst. 2007, 40, 658674.

Bernstein, F. C.; Koetzle, T. F.; Williams, G. J. B.; Meyer, E. F.; Brice, M. D.; Rodgers, J. R.; Kennard, O.; Shimanouchi, T.; Tasumi, M. J. Mol. Biol. 1977, 112, 535-542.

Sheldrick, G. M. Acta Crystallogr. 2008, A64, 112-122.

Emsley, P.; Lohkamp, B.; Scott, W. G.; Cowtan, K. Acta Crystallogr. 2010, D66, 486-501.

Murshudov, G. N.; Vagin, A. A.; Dodson, E. J. Acta Crystallogr. 1997, D53, 240-255.

Collaborative Computational Project Number 4. Acta Crystallogr. 1994, D50, 760-763. 


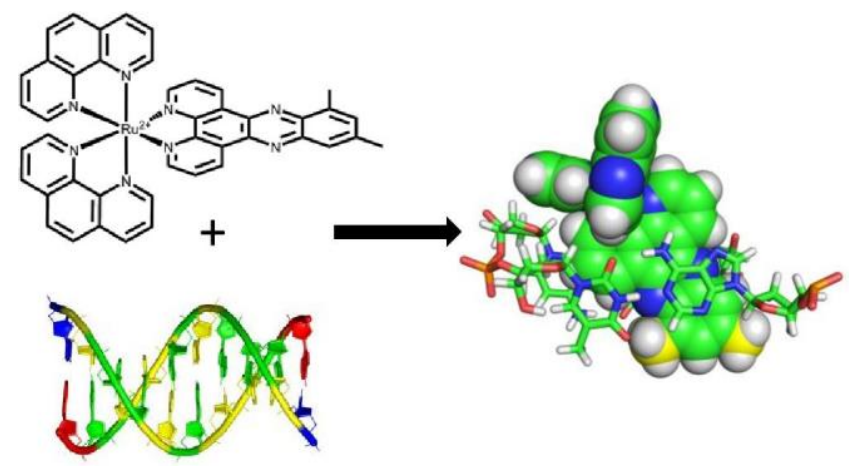

